\title{
Deutiches Qejebud
}

fưr

\section{böhere $\mathfrak{M a ̈ b d h e n i d u l e n ~}$}

von

\author{
Rarl Gellel.
}

\author{
Günfter Teil \\ Gïnfte Rlaffe.
}

Bierzebnte, unverănberte 2uflage.

Bonn 1919.

A. Marcus und E. Webers Betlag. 
